eytoplasm. The latter was of fine, granular appearance, with occasional clusters of denser granules (150-400 A. in diameter) in the polar regions of the bacilli, but no true mitochondria. Dividing cocci showed clear indications of the cytoplasmic vacuoles associated with ingrowing cell walls as demonstrated by Chapman and Hillier for Bacillus cereus ${ }^{8}$. (See also Birch-Andersen, A., Maaløe, O., and Sjöstrand, F. S., Biochim. Biophys. Acta, 12, 395 (1953), whose paper on electron microscopy of sectioned bacteria appeared after the above was submitted for publication.)

Our main interest, however, has been in the nuclei, both because of their controversial status and because of their possible significance for studies on the evolution of the nuclear apparatus of higher organisms'. As regards the existence of bacterial nuclei, our observations confirm and extend the already strong evidence for the presence in bacteria of bodies which in two respects-chemistry and morphologyhave much in common with the nuclei of animals and plants. There certainly are differences, for example, the degree of development of the nuclear membranes, but in the present state of knowledge the differences seem less conspicuous than the similarities.

The third major criterion of nuclear identity is behaviour at cell division. It is in this respect that bacterial nuclei appear to differ markedly from animal and plant nuclei, and from this point of view, therefore, they may be of outstanding interest for studies of nuclear evolution. It is perhaps a forlorn hope that the evolution of the protoplasmic organelles of animals and plants can ever be traced by study of modern micro-organisms. But at least it may be possible, without prejudicing any evolutionary issues, to distinguish three main levels of 'nuclear' organization (excluding those small viruses which contain no deoxyribonucleic acid) : (a) co-existence of deoxyand ribonucleic acid without such structural adjuncts as chromosomes, nucleoli and well-defined nuclei, clearly distinguishable from cytoplasm-that is, the state of affairs which presumably exists in many small and medium-sized viruses; $(b)$ localization of deoxyribonucleic acid and nuclear ribonucleic acid on special structures (chromosomes and nucleoli) within a moderately well-defined nucleus, which, however, divides amitotically - the condition characteristic of the bacteria here described and possibly of some large viruses; (c) the animal and plant condition, in which a fully differentiated nucleus divides by mitosis. However, great refinements of cytochemical techniques are needed before the wide variety of micro-organisms already recognized can be adequately surveyed and classified from this point of view.

I am indebted to Dr. R. M. Fry and Mr. R. C. Valentine for supplying me with the bacterial cultures used in this work.

'Robinow, C. F., in nubos, "The Bacterial Cell", 353-57 (Harvard University Press, 1945).' Bisset, K. A., "Cytology and Life-history of Bacteria" (Edinburgh, 1950). Knaysi, G., "Elements of Bacterial Cytology" (2nd edit, Ithacs, N.Y., 1951).

2 Tulasne, R., and Vendrely, R., Nature, 160, 255 (1947). Palade, G. E., J. Exp. Med., 95, 285 (1951). Bradfleld, J. R. G.,
Quart. J. Micr. Sci., 94, 351 (1953).

4 Bretschnelder, L. H., Proc. Kon. Akad. v. Wetensch., 52, 301 (1949).

"Danielli. J. F., "Cytochemistry" (London, 1953). Bradfleld, J. R. G., Biol. Rev., "25, 113 (1950).

' Wilson, k. B., "The Cell in Development and Heredity" (3rd edit., New York, 1928).

"Robinow, C. F., and Cosslett, V. E., J. App. Phys., 19, 124 (1948). Kellenberger, E., Experientia, 8, 99 (1952).

${ }^{8}$ Chapman, G. B., and Hillier, J., J. Bact., 66, 362 (1953).

- Caspersson, T., Symp. Soc. Exp. Biol., 1, 127 (1947).

\title{
FISHERIES SURVEY OF THE MAURITIUS-SEYCHELLES AREA
}

A $S$ the result of a recommendation in 1945 by Dr. J. F. G. Wheeler, a Colonial Development and Welfare Research Grant was made available for a survey of the fisheries resources of the MauritiusSeychelles region of the Indian Ocean. The survey was carried out during the two years 1948-49 by Dr. Wheeler and Dr. F. D. Ommanney, and a comprehensive report has now been published*.

Between the Seychelles and Mauritius and forming with them an arc of a circle, the centre of which, six hundred miles away, is the north end of Madagascar, there is a chain of shallow banks which, except for a few isolated islets, are never uncovered by any tide. The object of the survey was to assess the potential fish resources on and around those banks. The work was carried out mainly in a 70-ft. Scottish-type fishing vessel (M.F.R.V. 1), which made forty-two cruises providing approximately $285 \frac{1}{2}$ hours of fishing time. Ancillary observations were made in a schooner and certain other craft from the Seychelles and in small boats and pirogues at Mauritius.

It was found that the only fishable waters for demersal fish are on the banks themselves, as their edges fall away precipitously into great depths. Generally speaking, the best catches were made in

- Colonial Office Fishery Publications, 1, No. 3; 1953. Report on the Mauritius-Seychelles Fisheries Survey, 1948-1949. Part 1 The Bottom Fishes of Economic Importance. By J. F. G. Wheeler. Part 2: The Pelagie Fishes and a Note on Tow Nettings. By F. D Ommanney. Part 3 : Note on Meteorology. By F. D. Ommanney. Part 4 : General Considerations and Conclusions. By J. F. G. W depths of 8-42 fathoms, and the hand-line proved to be the most effective fishing instrument. It was, in fact, demonstrated that catching-rates by the simple, inexpensive and fool-proof method of hand-lining equalled those of trawlers using complicated and expensive trawling gear in normal trawling areas.

There are some 3,300 sq. miles of fishable water within an overnight run from Mahé (Seychelles) and $7,500 \mathrm{sq}$. miles within three days 'steaming' distance at 8 knots. There is very much less fishable water within the same distance of Mauritius; but the extensive St. Brandon and Nazareth Banks are not more than four days 'steaming' distance away.

Pelagic fishes, strangely enough, were also found to be almost entirely restricted to waters inside the 100-fathom line over the banks and close inshore around the islands. These consisted of a wide range of species from giant sailfishes and swordfishes down to mackerels, anchovies, sardines and the like. No method of capturing any of these on a paying commercial scale was discovered, so pelagic fishing is considered to hold fewer prospects of profitable development than bottom fishing.

The demersal fish resources of the region, on the other hand, are regarded as exploitable and adequate for all foreseeable local needs, and there could well be an exportable surplus if an outlet on the East African mainland could be found and developed.

At present the fish stocks of both the Mauritius and Seychelles areas are exploited only in very small 
measure over restricted areas near the inhabited islands. In due time, says the report, development will come, "but the pattern of its realisation is for others to decide". That, of course, must be so, for both Dr. Wheeler and Dr. Ommanney have now left the region; but it would have been helpful if, out of their knowledge and experience, they had offered more precise guidance to those whose lot some day it will be to do the developing. On one point, however, the report is quite clear and emphatic-any power-driven craft that may eventually be used for either fishing or further research on the grounds surveyed must be well-found, mechanically reliable, and carry really competent engineers. Wheeler and Ommanney's survey was beset with far too many avoidable difficulties and disappointments due to machinery failures. In the words of the report, their cruises went forward "under the urgency of impending break down". This applied not to one cruise only, but to all of them, for in the summarized log of the forty-two cruises there are no fewer than twentynine entries relating to mechanical failure of one kind or another, arising largely from unskilled attention.

The authors are very well aware that many of their conclusions are based on data that are regrettably 'thin'. In view of the inadequate facilities with which they were provided and the difficult conditions in which they worked, this is not surprising. What is remarkable is that so much was accomplished in spite of the difficulties. This was entirely due to the calibre of those in charge of the survey, and especially to the skill and competence of Skipper Davies, captain of M.F.R.V. 1, who was no less expert in the engine-room than in the wheelhouse ; it was due to his skill that on every occasion of machinery failure emergency repairs were made and "the long drift to Africa never eventuated". The measure of the hazards under which skipper and scientists worked (due to the ever-present threat of machinery breakdown) may be gauged from the fact that out of sight of land no other ship of any kind was seen during the entire commission and no contact was possible with either Seychelles or Mauritius on the effective range of their radio-telephone. In short, this survey by Wheeler and Ommanney was a truly heroic enterprise carried out in conditions that no one in an officially sponsored project of this kind should be asked or expected to contend with.

It will be the fervent hope of all those in any way connected with Colonial fisheries development and research that the Colonial Office and its advisers will pay particular heed to those sections of the MauritiusSeychelles report that emphasize the importance of mechanical efficiency in sea-going vessels. The M.F.R.V. 1 was placed in the "willing but inexperienced hands of local mechanics", and the survey suffered accordingly. Fisheries development in Colonial territories must depend in large measure on power-driven craft. To maintain them in good and reliable working condition, where ordinary servieing arrangements are either poor or entirely lacking, demands engineering skill of the highest order. To attract engineers of the right calibre into such service requires that both salaries and working conditions be really attractive. Salaries but little higher than those obtainable in the United Kingdom or in other less-exacting posts will attract only low-grade talent with its attendant low efficiency. Such parsimony is entirely false economy. True economy lies in attracting and keeping staff of such quality that worth-while results will be obtained despite diffculties. Projects that flounder or founder through lack of talent in those entrusted with the work are wasteful in the extreme, no matter how tight-fistedly they are financed.

\section{G. A. Steven}

\title{
THE HOXNE INTERGLACIAL RECONSIDERED
}

\author{
By R. G. WEST \\ Subdepartment of Quaternary Research, Botany School, University of Cambridge
}

\begin{abstract}
$\mathrm{T}$ HE Interglacial deposits at Hoxne, Suffolk, occupy a critical position in the Pleistocene stratigraphy of the British Isles. They directly overlie the Kimmeridgian Boulder Clay, contain an Acheulean industry and are covered by deposits of a later glaciation. The dating and the stratigraphy of the deposits are therefore of great importance. New evidence concerning both has recently been obtained by the application of pollen analytical methods and by an extensive programme of boring.

The deposits have been described in detail by Prestwich ${ }^{1}$, Clement Reid ${ }^{8}$ and Reid Moir $^{3,4}$. The accepted scheme of stratigraphy is based on the work of Clement Reid and Reid Moir. The succession described by Clement Reid and his climatic inferences from the plant remains are shown in Fig. $1 a$. Later, Reid Moir described sections in the Oakley Park pit which showed that the Palæolithic Loam rested directly on the Kimmeridgian Boulder Clay and was overlain by a deposit he believed to be glacial, and that it contained a temperate fauna and flora. $\mathrm{He}$ accepted Clement Reid's scheme of the stratigraphy and considered the Palæolithic Loam or so-called "upper temperate brickearth" to be younger than
\end{abstract}

the beds $B, C, D$ and $E$ of Clement Reid, although it lay directly on the boulder clay. He was then able to complete the climatic succession to the top of the deposits. The resulting scheme of stratigraphy and climatic change, shown in Fig. $1 a$, is a composite one, as the beds attributed to a position above the gravel $B$ were described by both Clement Reid and Reid Moir from sections at the north and west faces of the Oakley Park pit, whereas the older beds $B, C, D$ and $E$ were described from the south-west corner of the Old Brickfield, on the opposite side of the Eye-Hoxne road, where the full presumed sequence could not be seen.

The pollen diagram obtained from an excavated section on the west face of the Orkley Park pit, at point 1 in Fig. $1 b$, is exactly similar to the diagram obtained from the cores of a deep boring made at point 2, Fig. 16 , in the south-west part of the Old Brickfield. The similarity of the pollen diagrams shows that Clement Roid's Palxolithic Lorm and bed $E$ are of the same age. A large number of borings made in the area gave the stratigraphy shown in Fig. $1 b$. Both the pollen analytical and stratigraphical evidence prove that there is only one 